\title{
Prześniona rewolucja
}

Andrzej Leder, Prześniona rewolucja. Ćwiczenie $z$ logiki historycznej, Seria Historyczna, Wydawnictwo Krytyki Politycznej, Warszawa 2014, ss. 204.

W książce Prześniona rewolucja. Ćwiczenie z logiki historycznej Andrzej Leder - psychoterapeuta oraz filozof kultury, profesor w Instytucie Filozofii i Socjologii Polskiej Akademii Nauk - formułuje tezę, iż w latach 1939-1956 nastapiła w Polsce rewolucja społeczna. Książka odbiła się szerokim echem wśród naukowców i publicystów. W niniejszym tekście spróbuję zebrać opinie na jej temat oraz przedstawić własne wnioski.

Andrzej Leder próbuje przekonać do swoich tez za pomoca kolejnych argumentów, które zostają omówione w pięciu rozdziałach. Całość poprzedza wstęp o charakterze metodologicznym, w którym autor przywołuje przede wszystkim kategorie $z$ psychoanalizy Jacques'a Lacana, takie jak pole symboliczne, fantazmat, transpasywność. Wybór tej metodologii jest uwarunkowany przedmiotem badań, ponieważ Lederowi nie chodzi tylko o historię wydarzeniowa, ale także o tę, która rozgrywa się na poziomie dyskursu i świadomości społecznej.

Tytułowa „prześniona” rewolucja, choć ranga dorównuje Wielkiej Rewolucji Francuskiej, zdaniem Ledera nie została w dostateczny sposób w Polsce uświadomiona. W konsekwencji wywołuje różne dysfunkcje społeczne, których etiologia nie jest współcześnie dość dobrze rozpoznana. Brak uświadomienia skutkuje niedostatecznym opracowaniem naukowym tematu oraz brakiem świadomości społecznej. Choć Leder odnotowuje wydane w ostatnich latach prace: Grzegorza Niziołka Polski teatr Zagłady, Jana Sowy Fantomowe ciało króla i Marcina Zaremby Wielka trwoge ( $\mathrm{z}$ tych dwóch 
ostatnich często korzysta w swojej książce), to twierdzi, że konsekwencje wydarzeń historycznych interesujacego go okresu nadal nie zostały uświadomione. Stąd właśnie centralna metafora „prześnienia”, a zamierzeniem autora jest „przebudzenie” społeczeństwa. Najistotniejsze w omawianym przez Ledera okresie wydarzenia, takie jak na przykład zniszczenie ziemiaństwa czy zagłada Żydów, sa postrzegane przez „polski podmiot polityczny” jako rozgrywajace się bez jego udziału, w sposób bierny. Przeciwieństwem owego snu - „jawa” - jest współczesna rzeczywistość mieszczańska, której podmiot błądzi w poszukiwaniach własnej tożsamości między nieuzasadnienie eksploatowanym mitem przeszłości szlacheckiej a wzorcami, których dostarcza zglobalizowany świat. Leder, odwołując się do Waltera Benjamina, pragnie dokonać egzegezy współczesnego imaginarium poprzez przywołanie wydarzeń z przeszłości. Udział w rewolucji lat 1939-1956 miał się dokonywać transpasywnie, podobnie jak tłumaczony jest udział Niemców w zbrodniach nazistów w książce Daniela J. Goldhagena Gorliwi kaci Hitlera. Zwyczajni Niemcy i Holocaust. Wnioski, zdaniem Ledera, wypływaja stąd dwa: gorliwość wiąże się z przyjemnością, co umożliwia włączenie się w obręb wspólnej odpowiedzialności, a rozkaz pozwala na transpasywne „roztopienie się” w odpowiedzialności zbiorowej. Przyjemność ze zbrodni, których dokonuja inni, powoduje zatem, że podmiot ja odczuwający również zostaje współwinny. Autor Prześnionej rewolucji przywołuje książkę Goldhagena i polemizuje $z$ Marcinem Zaremba, ponieważ przyjemność czerpana ze zbrodni, nawet dokonywanych przez innych, sprawia, iż podmiot staje się wówczas aktywny, a nie jedynie biernie odczuwa strach.

Uzasadnienie tego przekonania wywodzi Leder $z$ faktu drastycznych nierówności społecznych właściwych „przedrewolucyjnej” Polsce. W rozdziale zatytułowanym Rewolucja, w którym określa warunki możliwości dokonania się tego procesu, pisze o cierpieniu, zawsze i koniecznie domagającym się kary, która może zostać wymierzona również pośrednio. Zauważa, iż w 1939 roku „[...] skryte do tej chwili, "złe" pragnienia dużej części polskiego społeczeństwa 
zostały zrealizowane przez innych. Choć najbardziej podmiotowe części narodu nie utożsamiały się $z$ decyzjami, działaniem i odpowiedzialnościa za to, co się stało, mściwe uczucia upokorzonych nagle zaczęły krystalizować się w wydarzeniach, realizować bezwiednie, jak we śnie" (s. 44). Taka jednak pewność dotycząca owej siły rewolucyjnej, która miała przeżywać transpasywną rozkosz $z$ faktu eksterminacji polskiego ziemiaństwa czy żydowskiej burżuazji, bierze się z założenia o powszechnym przekonaniu dotyczacym uświadomionej krzywdy wynikającej $z$ przyrodzonych podziałów na warstwy społeczne.

Analizy autora dotyczace funkcjonowania Żydów w Polsce eksponuja dystans dzielący społeczność żydowską od chłopów ${ }^{1}$. Ów dystans oraz poczucie ucisku chłopstwa przez żydowska burżuazję miały tłumaczyć bezrefleksyjne przejmowanie mienia ofiar Holocaustu, co na poziomie podświadomości było forma rekompensaty za doznane wcześniej krzywdy. Obecne zapomnienie tych faktów ma stanowić o wypieranym poczuciu winy dręczącym spadkobierców zagrabionego mienia.

W innym miejscu autor formułuje ogólne diagnozy dotyczace funkcjonowania społeczeństwa, takie na przykład jak: „Liberalna demokracja nie lubi silnych uczuć i związanych $z$ nimi symboli. Oparta na kompromisie, szanuje umiarkowanie i rozsądek, a nie miłość, nienawiść i walkę do ostatniej kropli krwi. Woli współczucie i ironię, stąd kariera dobroczynności i kabaretów” (s. 41).

Utrwalone i wszechogarniajace poczucie krzywdy powoduje rozszczepienie (termin psychoanalityczny) sposobu widzenia świata, w wyniku którego dostrzegane jest tylko dobro lub zło. Środki przekazu, takie jak przedwojenny „Mały Dziennik” czy współczesne Radio Maryja, sa jego wyrazem i buduja „uniwersa symboliczne”. Tymczasem w „uniwersum symbolicznym” demokracji nie ma miejsca na cierpienie, ponieważ niweluje ono dystans, bez którego występuje brak przestrzeni dla polityki i spraw publicznych.

1 Interesującym przykładem, którego dotycza rozważania, jest zwrot „po żydowsku”, który oznacza robienie czegoś „na opak” (s. 56). 
Jako kolejne etapy rewolucji widzi autor przeprowadzone po wojnie reformę rolna oraz industrializację, które ostatecznie załamały przedwojenne imaginarium. Reforma rolna, obok Holocaustu, była najbardziej znaczącym czynnikiem w przemianach polskiej mentalności. Zmieniała panujące od wieków wyobrażenia kształtujace porządek społeczny. Dotychczas jednak rewolucyjny charakter tych przemian był zagłuszany przez narrację dotycząca problemów narodowych.

Leder odnosi się również do współczesnej sytuacji Kościoła katolickiego, który w jego opinii nie odpowiada na potrzeby mieszczańskiego społeczeństwa. Problem widzi w mentalności chłopskiej, charakteryzującej kler również dziś, a związanej z przemiana rewolucji ziemiańskiej, która spowodowała napływ chłopów do seminariów duchownych. W industrializacji natomiast dostrzega narzędzie terroru, ponieważ w fabrykach ostatecznie miały być produkowane czołgi strzegące nowego porządku symbolicznego.

W zakończeniu książki autor stwierdza, iż okres PRL-u był „strefą przejścia" między społeczeństwem stanowym a wielkomiejskim kapitalizmem. Robotnicy, niemający wpływu na społeczeństwo, ale też nieponoszący odpowiedzialności, nie różnili się znacznie od dawnych bezrolnych wyrobników. Stosunki społeczne, zdaniem autora, nosiły wówczas cechy „folwarczne”.

Proces „rewolucji” kończy się współcześnie na uprzywilejowaniu mieszczan; ich najbardziej znacząca część wywodzi się z peerelowskich elit, które wyłoniły się właśnie w latach 1939-1956. Rewolucja nadal jednak pozostaje „prześniona”; brak nowego, świadomego podmiotu politycznego wyrażał się choćby w mało zdecydowanych działaniach rządu Donalda Tuska.

Tezy Andrzeja Ledera spotkały się z żywym przyjęciem, a nawet zostały uznane za prowokację intelektualna ${ }^{2}$. Autorzy recenzji opublikowanych po wydaniu książki niekoniecznie sa jednak do tych tez przekonani. Żaden bowiem $z$ autorów pięciu artykułów recenzyj-

2 Zob. S. Obirek, sine titulo (recenzja książki Prześniona rewolucja), „Zagłada Żydów. Studia i Materiały" 2015, nr 11, s. 715. 
nych przeanalizowanych na potrzeby niniejszego tekstu (Małgorzata Budyta-Budzyńska ${ }^{3}$, Stanisław Obirek ${ }^{4}$, Teresa Walas ${ }^{5}$, Wojciech Engelking ${ }^{6}$, Michał Przeperski ${ }^{7}$ ) nie zgadza się $z$ nimi w pełni. Prześniona rewolucja prowokuje do myślenia i jest niewątpliwie nowatorska propozycja dotycząca genealogii polskiej klasy średniej, ale musi się zmagać z zarzutami o brak uzasadnienia empirycznego dla prezentowanych wniosków, brak rzetelnych badań, a także wybiórczość potraktowania tematu i nieścisłości terminologiczne. Choć jednak również pojęcie tytułowej „rewolucji” budzi wattpliwości badaczy, którzy stawiają pytania o jego adekwatność, sądzę, że poruszenie, które wywołała ta publikacja oraz typ zaproponowanych w niej analiz sa nowatorskie i rewolucyjne. Spróbuję zebrać oraz podsumować najważniejsze uwagi zarówno odrzucajace, jak i aprobujące tezy pracy Ledera. Oś analizy będzie się tworzyła wokół rewolucyjnego charakteru wydarzeń historycznych, przeżywanych transpasywnie przez formułujaca się, przyszłą klasę średnią oraz rewolucyjnego charakteru owego przeżycia dla podmiotu.

Prześledzę zatem kolejne teksty i uporzadkuję zawarte w nich oceny, opinie i polemiki z Prześniona rewolucja, odpowiadając jednocześnie na pytania: „Kto jest podmiotem tej rewolucji?”, „Dlaczego mogła się dokonać?” oraz „Jaki jest jej skutek?”. Zawężenie pola rozważań wynika $z$ wielości wątków poruszanych przez autorów kolejnych recenzji i nie jest jednocześnie ograniczeniem, ponieważ sa to centralne tematy książki. Odpowiedź na te pytania pozwoli także na doprecyzowanie terminu „rewolucja” i przypisaną mu przez Ledera treść oraz rozstrzygnięcie, czy opisywane wydarzenia faktycznie miały charakter rewolucyjny.

\footnotetext{
3 M. Budyta-Budzyńska, Bezalternatywna, narzucona zmiana społeczna czy prześniona rewolucja? Na marginesie książki Andrzeja Ledera, „Kultura i Społeczeństwo” 2014, t. 58, nr 3.

4 S. Obirek, sine titulo... .

5 T. Walas, Genealogia klasy średniej z Lacanem $w$ tle, „Nowa Dekada Krakowska” 2015, nr $1-2$.

6 W. Engelking, Zemsta słabych? Na marginesie „Prześnionej rewolucji” Andrzeja Ledera, „Kronos” 2015, nr 1 (32), s. 306-307.

7 M. Przeperski, Nie nasza rewolucja, „Znak” 2014, nr 710-711, s. 112.
} 


\section{Kto jest podmiotem tej rewolucji?}

O zasadność stosowania terminu „rewolucja” w kontekście doświadczenia Polaków w latach 1939-1956 pyta już w tytule swojego artykułu Małgorzata Budyta-Budzyńska. Autorka zastanawia się, czy wydarzenia opisane przez Ledera to Bezalternatywna, narzucona zmiana społeczna czy prześniona rewolucja. W recenzji przywołane zostają definicje rewolucji, w które wydarzenie $z$ książki Ledera się nie wpisuje. Zdaniem badaczki rewolucje sa ze swojej natury „endogenne” i stanowią dzieło społeczeństw, w których wybuchały. Rewolucja, o której pisze Leder, była przełomowa, ale sposób jej wprowadzenia nie miał charakteru rewolucyjnego bo nie został przeprowadzony przez podmiot, którego dotyczy.

Pominięty zostaje tu jednak fakt „prześnienia” rewolucji, o której traktuje książka. Leder analizuje wydarzenia historyczne w perspektywie psychoanalitycznej, a zatem teatr rewolucji, o której pisze, rozgrywa się również w świadomości podmiotu, który w ten sposób zyskuje sprawczość. Psychoanaliza nie jest tu tylko metodologia, lecz mówi po prostu o faktach niedostrzegalnych w klasycznym dyskursie naukowym, a, zdaniem autora, równie istotnych jak te opisywane przez historię wydarzeniowa. W tym subtelniejszym do uchwycenia sensie rewolucja jest zatem endogennym dziełem polskiego podmiotu politycznego. Leder już na pierwszych stronach swojej książki dokonuje rozróżnienia na poziom faktów historycznych oraz poziom świadomości/nieświadomości społecznej (s. 5). Co więcej, ten drugi poziom zostaje przez niego określony jako „kluczowy dla zrozumienia rzeczywistego przebiegu procesu społecznego" (s. 262). Nawet jednak gdy pozostaniemy tylko na poziomie wydarzeń historycznych, to antysemityzm czy niechęć chłopów wobec panów były faktami endogennie właściwymi polskiemu społeczeństwu.

Można się zastanawiać nad dostateczna skalą tego problemu, która pozwoliłaby na szerszy proces upodmiotowienia i w konsekwencji wyodrębnienia samoświadomej klasy średniej. Takie wąt- 
pliwości wyraża Małgorzata Budyta-Budzyńska, a także Stanisław Obirek oraz Teresa Walas. Ta ostatnia autorka bardzo starannie podąża za tokiem wywodu Ledera i stawia pytanie o możliwość tego typu upodmiotowienia ze względu na charakter przemian oraz zakres jouissance ${ }^{8}$. Punkt wyjścia, czyli rewolucja lat okupacji i okresu powojennego, nie jest oczywisty, ponieważ w omawianej książce rewolucja „obejmuje [...] wszelką gwałtowna zmianę stosunków i stanu własności oraz społecznej hierarchii, niezależnie od rodzaju sił, które ja wywołały", a zmiana taka równie dobrze może być skutkiem „kataklizmu o charakterze przyrodniczym”, na co przecież podmiot społeczny nie ma żadnego wpływu. Trudno zatem uznać tego typu wydarzenia za konstytutywne dla polskiej klasy średniej.

Walas definiuje jeszcze rewolucję jako „przewrót społeczny, którego realną siłę sprawczą stanowi określona klasa/grupa społeczna, wyposażona we własny projekt ideologiczny, czyli pole symboliczne, które $z$ chwila zwycięstwa narzuca szerszej zbiorowości”. Ta definicja nie ma tu jednak zastosowania, ponieważ nie istnieją żadne dowody na to, że nawet część społeczeństwa w sposób upodmiotawiajacy przeżywała rozkosz wynikłą $z$ transpasywnej zemsty na Żydach. Odwołując się do Jana Strzeleckiego, autorka zauważa, że podczas niemieckiej okupacji norma były raczej niedostatek, strach i upokorzenie. Jeśli natomiast chodzi o akt „prześnionej rewolucji” pod postacia reformy rolnej, to wiarę w powodzenie tego „projektu” skutecznie odbierało chłopom widmo

\footnotetext{
8 Francuskie słowo jouissance nie ma dokładnego odpowiednika w języku polskim. Najbliższe wydają się mu słowa „,rozkosz”, „rozkoszowanie się”, jednak nie określają one dokładnie tego, co ów termin zawiera. „Termin jouissance nie odwołuje się do przyjemności doznawanej w ramach zasady przyjemności, dotyczy bowiem obszaru poza zasada przyjemności. Jouissance może być doświadczana w różnych doznaniach życia seksualnego, w bólu, w cierpieniu, we wszystkich przypadkach, w których łączą się popęd życia $z$ popędem śmierci. Zbliżenie się do tego obszaru jest trudne, ponieważ dotyczy on tego, co wymyka się symbolizacji. Jouissance przedstawia się jednocześnie jako mityczna i jako realna. Dotyczy podmiotu, lecz wymyka się subiektywizacji. Doświadczona w ciele może być nieświadoma". Krakowskie Koło Psychoanalizy Nowej Szkoły Lacanowskiej, http://www.psychoanaliza.com. $\mathrm{pl} /$ ?art=3\&tab=mps\&lang (dostęp: lipiec 2017, przyp. red.).

9 T. Walas: Genealogia..., s. 146.
} 
bolszewizmu. Brakowało zatem grupy społecznej, która rewolucję nawet na tym drugim wyróżnionym przez Ledera poziomie mogła przeprowadzić i sformułować jej cel.

W recenzji autorstwa Wojciecha Engelkinga zatytułowanej Zemsta słabych? Na marginesie „Prześnionej rewolucji” pojawia sie również argument o tych, którzy nie skorzystali $z$ parcelacji majątków, ponieważ reforma rolna oznaczała przede wszystkim brutalne przesiedlenie, które właśnie słabym odebrało podmiotowość; przesiedlano ich na tereny, gdzie nie było majątków Sapiehów.

Wattpliwości autorów w kwestii możliwości oszacowania liczby osób cieszących się $z$ nieszczęścia Żydów czy korzystających z krzywdy dawnych panów nie oznaczaja, że taka mała grupa nie mogła później narzucić swojej narracji grupie większej. W ramach historii wydarzeniowej rewolucjoniści moga też konspirować. $\mathrm{Na}$ temat okresu ponapoleońskiej rewolucji Eric Hobsbawm pisał: „Wszyscy rewolucjoniści uważali się, poniekąd słusznie, za wyemancypowana i postępową elitę, działająca pośród i na rzecz ogromnych oraz biernych mas niewykształconych i ogłupionych prostych ludzi, którzy $z$ pewnościa przyjęliby nadchodząca wolność, ale na których w walce o nia nie można zbytnio polegać"10. Argument „ilościowy” dotyczący przeżycia wyzwalającego rewolucję, jeśli odniesiemy ten cytat do książki Ledera, nie jest zatem do końca trafny. Podmiot polityczny w naszym przypadku niczego jeszcze o sobie nie uważał, choć można przypuszczać, że za „ogłupionych" brał tych, którzy nie korzystali z żydowskiej tragedii, jeśli nadarzyła się ku temu okazja, a także tych, którzy nie korzystali gorliwie $z$ dobrodziejstw reformy rolnej. Krótko mówiąc, rewolucjonistów nie musiało być wielu po to, aby ich doświadczenie miało później szerszy skutek. Prócz tego każda rewolucja może się okazać dla części społeczeństwa „prześniona”, niezależnie od tego, czy jej czynnym podmiotem są wykształcone elity, czy niewykształceni chłopi.

${ }^{10}$ E. Hobsbawm, Wiek rewolucji 1789-1848, przeł. M. Starnawski, K. Gawlicz, Wydawnictwo KP, s. 173. 


\section{Dlaczego mogła się dokonać?}

Choć odpowiedź na to pytanie częściowo już została udzielona, należy ją jeszcze doprecyzować. Z Prześnionej rewolucji wynika, że podstawa zwrotu w dwudziestowiecznej historii Polski były „uczucia rewolucyjne” i ich amplitudy skorelowane $z$ wydarzeniami w historii. Małgorzata Budyta-Budzyńska na potrzeby analizy książki Ledera dokonuje nawet wyliczenia typu uczuć, które powinny towarzyszyć każdej rewolucji. Sa to zatem: „uniesienie”, „euforia”, „entuzjazm” i „optymizm” oraz „wiara w lepsza przyszłość". Takich uczuć, zdaniem autorki, brakowało jednak polskiemu podmiotowi politycznemu w omawianym okresie i dlatego teza o rewolucyjności dziejacych się wówczas wydarzeń nie jest zasadna. Argument ten nie wydaje się do końca trafny, ponieważ inny autor, Bronisław Baczko, teoretyk Rewolucji Francuskiej, tworzy przeciwstawny katalog uczuć napędzających bieg rewolucji: „Jeśli szukamy najmniejszego wspólnego mianownika między pamfletami Sieyèsa, rozruchami chłopskimi a zbuntowanymi tłumami paryskimi, to sa nim pasje antyszlacheckie, nienawiść do szlachty i jej przywilejów, poczucie słuszności pomsty wymierzonej przez uciskanych i upokorzonych, pragnienie naprawienia krzywd i obietnica równości"11. Można zatem sądzić, że w przypadku polskiej rewolucji „wiara w lepsza przyszłość” - której nie dostrzega w polskim podmiocie politycznym okresu "prześnionej rewolucji” Małgorzata Budyta-Budzyńska - wynika $z$ "obietnicy równości", bo to właśnie ucisk i upokorzenie kierowały, zdaniem Ledera, ku zmianom świadomościowym. Nawet nie dokładnie o „obietnicę" tu chodzi, ponieważ obietnicę składa ktoś komuś lub ktoś sam sobie, i dlatego możemy mówić nawet o „wierze” w przyszłe zrównanie $z$ "panami” czy, pełniącymi funkcje mieszczan, Żydami. „Prześniona rewolucja” ma zatem cel pozytywny.

${ }^{11}$ B. Baczko, Rewolucja. Władza, nadzieja, rozterki, przeł. W. Dłuski, Słowo/obraz terytoria, Gdańsk 2010, s. 11. 
Z kolei Teresa Walas nie kwestionuje założeń Ledera, wedle których uczucia sterujące rewolucja moga być „ciemne”. Ma jednak watpliwości w kwestii ich faktycznej siły sprawczej, ponieważ jeśli nawet przyjąć, że podczas wojny ktoś przeżywał jouissance, to „wszechobecność okupacyjnego terroru i stałe poczucie zagrożenia w znacznej mierze rozkosz tę musiało mrozić, bo świadek w jednej chwili mógł stać się ofiarą"12.

Wątpliwości recenzentów pracy Ledera moga rozwiać badania empiryczne. Choć trudno w dokładny sposób zbadać, co w czasie wojny oraz bezpośrednio po niej czuli Polacy, to nie można kwestionować powtarzalności pewnych ludzkich zachowań. W książce Lecha Nijakowskiego o znaczacym tytule Rozkosz zemsty czytamy: „Dlaczego jednak zemsta ma być rozkoszna? Choć ludzie rzadko się do tego przyznaja, zemsta wzbudza pozytywne uczucia, wręcz euforię. Ludzki mózg czerpie przyjemność $z$ pewnych form zemsty. Obrazowanie za pomoca rezonansu magnetycznego (MRI) dowiodło, że myślenie o mszczeniu się pobudza ośrodek nagrody, podobnie jak czyni spożywanie słodyczy, a nawet przyjmowanie narkotyków"13.

Przewijające się w wielu recenzjach pytanie „Skąd autor wie, co czuli wówczas Polacy?”, znajduje zatem odpowiedź. Ponadto zarówno „negatywne”, jak i „pozytywne” uczucia, które kieruja podmiotem rewolucyjnym, moga $z$ siebie wynikać: myślenie o zemście jest przyjemne. Zemsta ma także funkcję strukturotwórcza, ponieważ osoby biorace udział na przykład w ludobójstwie zyskuja poczucie wspólnoty. Takie reakcje można było zaobserwować na przykładzie masakry Tutsi dokonanej przez Hutu w Rwandzie ${ }^{14}$. Konsekwencje zarówno dla czynnych, jak i dla biernych aktorów „prześnionej rewolucji” sa podobne, ponieważ transpasywnie „[...] pewne działania i przeżycia Innego moga być doświadczane jak własne, generujac stany emocjonalne, zwykle przypisywane własnej aktywności” (s. 21).

${ }^{12}$ T. Walas, Genealogia..., s. 147.

${ }^{13}$ L. Nijakowski, Rozkosz zemsty, Wydawnictwo Naukowe Scholar, Warszawa 2013, s. 16.

${ }^{14}$ Ibidem, s. 112. 
Pozostaje jednak podniesiona przez Teresę Walas kwestia możliwości błyskawicznej zamiany „sprawcy” w ofiarę. Jeśli nawet na podstawie „dokonywanej” podświadomie przez wielu sprawców zbrodni można ukonstytuować jakąś wspólnotę - przyszła polską klasę średnia - to akt owej zbrodni nie jest konsekwentny. Oczywiście podobna prawidłowość, czyli płynna zmiana między rola kata a rola ofiary, dotyczyła też innych rewolucji. Tu jednak ów mszczacy się transpasywnie polski podmiot polityczny od początku wiedział, że również jest ofiara. Uczucia wobec żydowskiego cierpienia to, jak pisze Marcin Zaremba, po pierwsze: satysfakcja (trudno tu dostrzec owa bierność podmiotu, która odnotowuje w rozważaniach Zaremby Leder) i pocieszenie wobec własnej degradacji do pozycji Untermenschen, a tym samym zapewnienie poczucia wyższości oraz po drugie: strach i lęk jako komponent każdego nacjonalizmu, również skierowanego przeciw Żydom ${ }^{15}$. Prócz tego Żydzi „mogli stać się nosicielami biologicznego wręcz strachu i lęku"16, bo za ich ukrywanie groziła kara śmierci. $Z$ doświadczenia traumy $z$ kolei wynika odrętwienie, a poprzez gniew, wściekłość, agresję niektóre ofiary starają się odzyskać siły życiowe ${ }^{17}$.

Nie ma zatem sprzeczności między byciem ofiara a czerpaniem satysfakcji $z$ tego, że Inny ma po prostu gorzej albo między byciem ofiara i jednoczesnym mszczeniem się za sprawa mechanizmów traumy na innych, jeszcze słabszych. Zaremba nieco bardziej niż Leder niuansuje kondycję psychospołeczna Polaków podczas wojny, ponieważ widzi odmienne problemy w Generalnym Gubernatorstwie i na Kresach, w zależności od stosunku okupanta do Żydów. Innych też uczuć doświadczali w konsekwencji Polacy wobec swoich eksterminowanych sassiadów. Nie pozostawał też bez znaczenia wpływ propagandy Trzeciej Rzeszy na masy niewykształconych i biednych, do których nie docierały empatyczne publikacje akowskie i komunistyczne ${ }^{18}$.

\footnotetext{
${ }_{15}$ M. Zaremba, Wielka trwoga. Polska 1945-1947. Ludowa reakcja na kryzys, Wydawnictwo Znak, Instytut Studiów Politycznych PAN, Kraków - Warszawa 2012, s. 136.

16 Ibidem.

17 Ibidem, s. 136-137.

${ }^{18}$ Ibidem, s. 135.
} 
Narracja Ledera, spójna ze względu na logikę psychoanalizy, nie uwzględnia jednak faktu, że rewolucja może obejmować tylko część społeczeństwa, ponieważ nie wszędzie w Polsce istniały odpowiednie warunki. W ten sposób zreszta można też odpowiedzieć na pytanie, dlaczego polska klasa średnia jest niedookreślona i miota się między wzorcami szlacheckimi a hiperglobalnymi: część społeczeństwa wyemancypowała się dzięki „prześnionej rewolucji”, część - dzięki możliwości awansu społecznego w PRL-u, a część czerpie swoją tożsamość $z$ jeszcze innych źródeł.

\section{Jaki jest jej skutek?}

Skutkiem rewolucji, wedle Ledera, jest pojawienie się nowej klasy średniej, o „prześnionej” tożsamości, czyli bez własnego uświadomionego imaginarium. Taki wniosek zaprzecza przyjętym definicjom rewolucji, na co zwracają uwage recenzenci książki. Wynikiem rewolucji powinny być znaczace symbole, takie jak Deklaracja praw człowieka $i$ obywatela czy zburzenie Bastylii. W przypadku książki Ledera można jedynie mówić o skutkach rewolucyjnych, ale nie o tym, że nastapiła rewolucja społeczna ${ }^{19}$. Powrót powojennej klasy średniej do imaginarium sarmackiego jest dowodem na brak rewolucji mentalnej ${ }^{20}$ lub też na dominację nacjonalistycznego uniwersum symbolicznego, narzuconego przez komunistów, które tłumaczy pogromy, a także bezkrwawe przejęcie majątku polskich właścicieli ziemskich ${ }^{21}$. Podawane jest też w wątpliwość „wielkie pchnięcie” jako następstwo prześnionej rewolucji, które było efektem planowanych już przed wojna zmian modernizacyjnych $^{22}$. Samo „prześnienie” i tym samym jakikolwiek możliwy skutek kwestionuje Stanisław Obirek: „A poezja, literatura, filozofia, polska szkoła filmowa, muzyka teatr - czy nie zaświadczyły

\footnotetext{
${ }^{19}$ M. Budyta-Budzyńska, Bezalternatywna..., s. 263.

20 T. Walas: Genealogia..., s. 148.

${ }^{21}$ M. Przeperski, Nie nasza..., s. 112.

${ }^{22}$ Piszą o tym fakcie w przywoływanych tekstach Wojciech Engelking i Teresa Walas.
} 
o zmaganiu się $z$ życiem całkiem świadomie? A już na pewno trudno w nich dostrzec realizację mściwych pragnień" ${ }^{23}$.

Teoria społeczeństwa sieci Manuela Castellsa mówi o „pojawieniu się historycznej różnorodności kulturowej”24, która właśnie umacnia się wobec sieci. Propozycja Ledera być może stanowi próbę takiego „umocnienia” własnej, polskiej tożsamości. Przy czym jest tylko jedna $z$ wielu mogących się toczyć równolegle narracji eksplikujących tożsamość polskiej klasy średniej. Interesująca, nowatorska i skłaniajacca ku dalszym badaniom tej kwestii.

Danuta Kisiała

${ }^{23}$ S. Obirek, sine titulo..., s. 712 .

${ }^{24}$ M. Castells, Władza komunikacji, przeł. J. Jedliński, P. Tomanek, Wydawnictwo Naukowe PWN, Warszawa 2013, s. 49.

Danuta Kisiała - doktorantka w Zakładzie Filozofii Polityki Uniwersytetu Warszawskiego, prowadzi badania nad reklama. 